\title{
Nipah virus: an update
}

\begin{abstract}
On May 19, 2018; first Nipah Virus (NiV) outbreak was reported from Kozhikode district of Kerala and Mallapuram district of South India. There is high risk of NiV outbreak to individual as well as community. NiV is classed across the world as a bio-safety level (BSL)-4 hazards. Emerging zoonotic risk grade-4 (RG-4): Hendra and Nipah viruses cause severe and often lethal respiratory illness (encephalitis particularly in sows, boars and human) and have public impact on human health [fever, aches, tiredness, chills \& nervous signs (twitching, trembling, muscle fasciculation, spasms, muscle weak spot, convulsions and death)]. Zoonotic diseases transfer to human being from animals. NiV can infect a huge variety of species. Transmission of $\mathrm{NiV}$ from human being to human being has been observed. They are associated with high risk (group-4) of life-threatening disease in human and/or animals. Treatment is restrained to supportive care. Because NiV encephalitis can be transmitted from one person to another person, standard infection control practices and proper barrier nursing techniques are important to prevent nosocomial transmission infections. For handling RG-4 Nipah virus, there is a requirement for a laboratory with extensive BSL-4 high level containment that includes practices (BSL-3 plus controlled access); safety equipment's (Biological Safety Cabinet, full-body air-supplied, positive pressure and personnel suit) and facilities (BSL-3 plus dedicated air and exhaust, decontamination procedures for exit, separate building) Biological safety cabinets use high efficiency particulate air (HEPA) filters in their exhaust and/or supply systems. A Power Air Purifying Respirator (PAPR) or tight-fitting goggles and N-95 respirator should be worn for high-risk aerosol-generating procedures. The therapeutic use of a neutralizing human monoclonal antibody targeting the Nipah G glycoprotein has experimentally been evaluated in the post-exposure therapy in the ferret model and found to be of benefit. Additional efforts focused on surveillance and awareness will assist save future outbreaks.
\end{abstract}

Keywords: henipavirus, hazards, pteropus bats, pigs, encephalitis, fatalities, bsl-4, bats
Volume 2 Issue 4 - 2018

\section{Vrish Dhwaj Ashwlayan, Saurabh Nimesh \\ Department of Pharmaceutical Technology, Meerut Institute of Engineering and Technology, India}

Correspondence: Vrish Dhwaj Ashwlayan, Department of Pharmaceutical Technology, Meerut Institute of Engineering and Technology, NH-58 Baghpat Crossing Bypass Road, India, Tel 91-9412493228, Email vrish.ashwlayan@miet.ac.in

Received: June 29, 2018 | Published: July 26, 2018
Abbreviations: BSL, bio-safety level; ELISA, enzyme-linked immunosorbent assay; HEPA, high efficiency particulate air; ICMR, international council of medical research; NiV, nipah virus; PAPR, power air purifying respirator; PCR, polymerase chain reaction; RG-4, risk group-4; RT-PCR, reverse transcription-polymerase chain reaction

\section{Introduction}

Microorganisms that commonly cause lethal human, animal and plant diseases that can promptly be transmitted from one individual to another, directly or indirectly are considered in risk group-4. NiV in Malaysia emerged a deadly disease of respiratory infections and neurologic diseases in commercially farmed pigs, prognostically after virus spill over from Malaysian flying foxes in 1998. Infection of NiV has not been detected in Malaysia or Singapore after 1999. From, 2001 to 2013 several Nipah outbreaks were reported in people of Bangladesh' districts. There have been 17 mortalities and 18 morbidities up to 01 June 2018. This was the first NiV outbreak in Kozhikode and Mallapuram districts in South India. ${ }^{1-4}$ However, annual cases of Nipah encephalitis (inflammation of meninges), sporadic outbreaks in human being with morbidity and mortality were recorded in India and in Bangladesh as per Table 1.5-8

According to the United States based Centers for Disease Control and Prevention, the signs of $\mathrm{NiV}$ infection are encephalitis and respiratory infection especially in sows and boars. The incubation period may vary from 04 to 14 days but can be prolonged up to 45 to 60 days. ${ }^{9}$

Table I Morbidity and mortality in human due to nipah virus

\begin{tabular}{llll}
\hline Month /year & Place & Cases & Deaths \\
\hline INDIA & & & \\
Jan-Feb 200I & Siliguri & 66 & 45 \\
Apr-07 & Nadia & 5 & 5 \\
May-June 2018 & Kerala & 18 & 17 \\
BANGLADESH & & & \\
Apr-May 200I & Meherpur & 13 & 9 \\
Jan-03 & Naogaon & 12 & 8 \\
Jan-04 & Rajbari & 31 & 23 \\
Apr-04 & Faridpur & 36 & 27 \\
Jan-Mar 2005 & Tangail & 12 & 11 \\
Jan-Feb 2007 & Thakurgaon & 7 & 3 \\
Mar-07 & Kushtia, Pabna, Natore & 8 & 5 \\
Apr-07 & Naogaon & 3 & 1 \\
Feb-08 & Manikgonj & 4 & 4 \\
Apr-08 & Rajbari and Faridpur & 7 & 5 \\
\hline
\end{tabular}


Table continued.....

\begin{tabular}{|c|c|c|c|}
\hline Month /year & Place & Cases & Deaths \\
\hline Jan-09 & $\begin{array}{l}\text { Gaibandha, Rangpur and } \\
\text { Nilphamari }\end{array}$ & 3 & 0 \\
\hline Feb-Mar 2010 & $\begin{array}{l}\text { Faridpur, } \\
\text { Rajbari,Gopalganj,Madaripur }\end{array}$ & 16 & 14 \\
\hline Jan-Feb 20II & $\begin{array}{l}\text { Lalmohirhat, Dinajpur, } \\
\text { Comilla, Nilphamari and } \\
\text { Rangpur }\end{array}$ & 44 & 40 \\
\hline Feb- 12 & $\begin{array}{l}\text { Joypurhat, Rajshahi, Natore, } \\
\text { Rajbari and Gopalganj }\end{array}$ & 12 & 10 \\
\hline Jan-Feb 2013 & $\begin{array}{l}\text { Gaibandha, Natore, Rajshahi, } \\
\text { Naogaon, Rajbari, Pabna, } \\
\text { Jhenaidah, Mymensingh }\end{array}$ & 12 & 10 \\
\hline
\end{tabular}

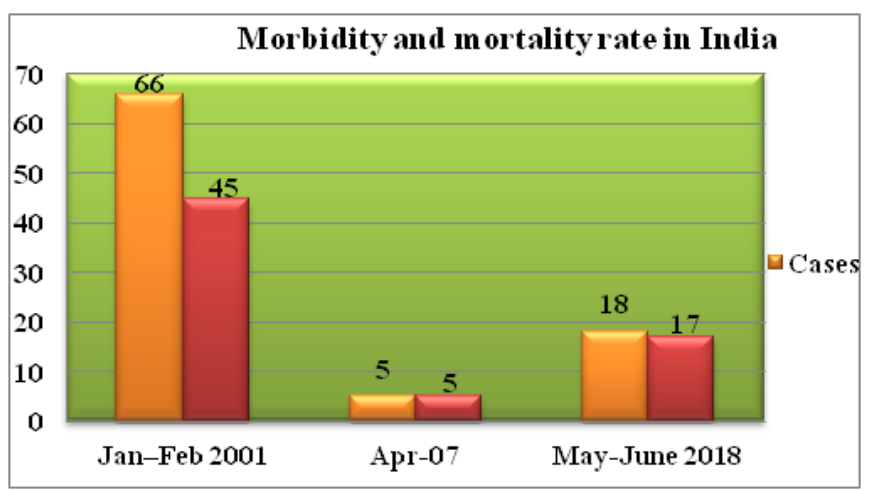

Figure I The graphical representation in morbidity and mortality rate in india.

\section{Clinical signs}

Encephalitis and respiratory (twitching, trembling, muscle fasciculation, spasms, muscle weak spot, convulsions \& death) are predominant in nerve of human beings Figure 1. Human beings, bats, sheep and domestic pets (pigs, dogs \& horses) are susceptible to NiV infection. But the observation could not be further confirmed. ${ }^{10}$ There is threat to the life of human being, ${ }^{11}$ and experimental animals such as ferret, guinea-pig \& hamster and in suckling mouse due to $\mathrm{NiV}^{12,13}$ $\mathrm{RG}-4$ virus. Henipa virus and Nipah virus genus of Paramyxoviridae family, risk group 4 (RG-4) hazard may lead to a viral zoonotic disease which is transmitted to human being through infected fruit, animals or via near touch with infected human being Figure 2. Safety equipment's: 4 or 3 level biological safety cabinet. The construction of class III biological safety cabinet available in India provides utmost personnel and environmental protection against infectious aerosols and new drug derived from biotechnology-pharmacy invention. Full-body air-supplied \{power air purifying respirator (PAPR) and $\mathrm{N}-95$ respirator\} or, gas-tight construction; Positive pressure: high efficiency particulate air (HEPA) filters in exhaust and/or supply systems. Personnel suit: tight-fitting goggles and N-95 respirator. ${ }^{14-17}$ There are two bio-safety level-3 (BSL-3) facilities for Microbiology laboratory and one for the animal experimentation in National JALMA Institute for Leprosy \& other Micro-bacterial Diseases under ICMR Tajganj, Agra. There are four laboratories with BSL -4 facilities Table 2 in which the virus may be studied safely without a risk of escaping and possibility of infecting a greater number of people Figure $3 .^{18}$

Table 2 List of BSL -4 facilities

\begin{tabular}{lll}
\hline S. No. & Name & Location \\
\hline I & $\begin{array}{l}\text { High Security Animal } \\
\text { Disease Laboratory }\end{array}$ & Bhopal Madhya Pradesh, India \\
2 & $\begin{array}{l}\text { Centre for Cellular and } \\
\text { Molecular Biology }\end{array}$ & Hyderabad, Telangana, India \\
3 & $\begin{array}{l}\text { Microbial Containment } \\
\text { Complex }\end{array}$ & Pune, Maharashtra, India \\
4 & $\begin{array}{l}\text { Instituto Nazionale per Le } \\
\text { Malattie Infettive }\end{array}$ & Rome, Lazio, Italy \\
\hline
\end{tabular}

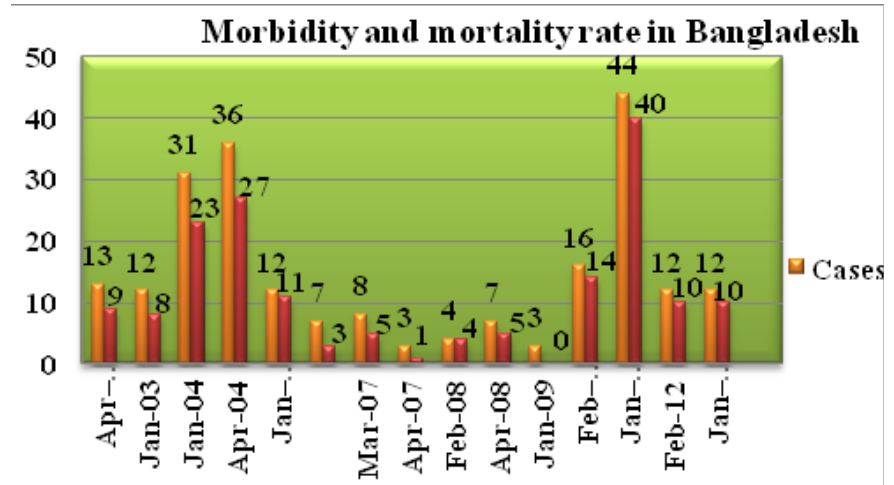

Figure $\mathbf{2}$ The graphical representation in morbidity and mortality rate in bangladesh.

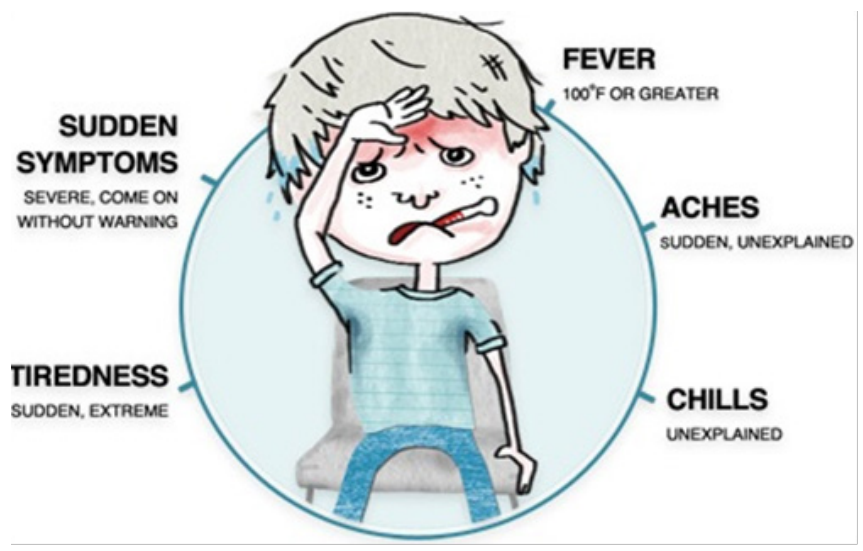

Figure 3 Signs in patient suffering from NiV infection.

\section{Treatment}

There are presently neither anti-viral drugs nor vaccines available to deal with $\mathrm{NiV}$ infection for human beings or animals. The primary treatment for human cases is intensive prophylaxes. Because NiV encephalitis may be transmitted one person to another, standard infection control practices and proper barrier nursing techniques are important to prevent hospital-acquired infections. Prophylactic 
treatment of the infection with ribavirin, anti-viral drug is effective against the virus's in-vitro, but usefulness of ribavirin remains clinically uncertain. The Nipah G glycoprotein was targeted with neutralizing human monoclonal antibody in the post-exposure therapy in the experimental ferret model and was found to be therapeutically effective Figure $4 .{ }^{19}$

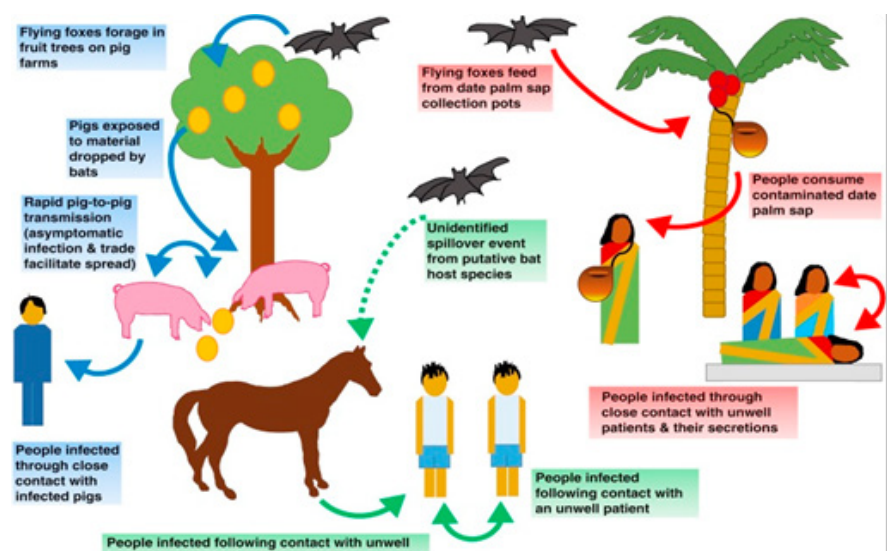

Figure 4 Transmission of nipah virus.

\section{Prevention}

Exposure to sick pigs and bats and drinking of raw date palm sap should be avoided to control endemic infection caused by NiV Figure 5.

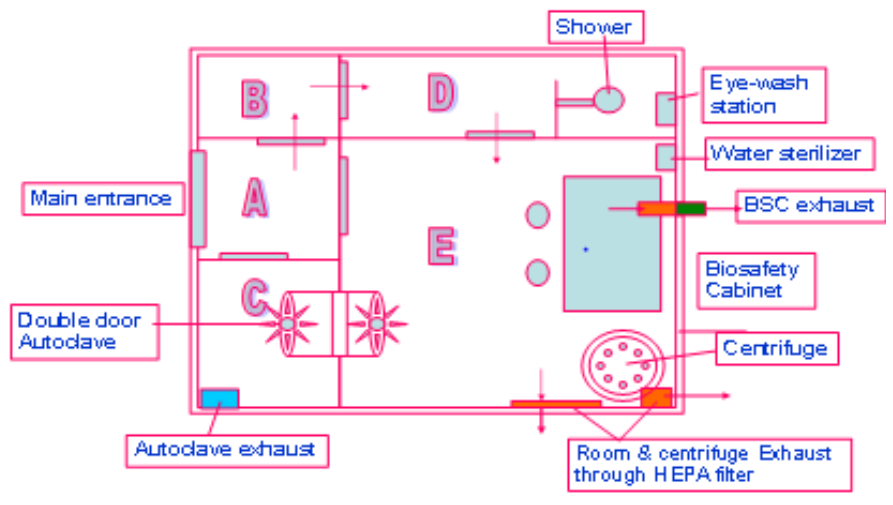

Figure 5 Lay-out of BSL-3 laboratory.

\section{Conclusion}

According to World Organization for Animal Health, Nipah virus is a noticeable disease of international importance. Most risk grade- 4 (RG-4) infectious hazard leads to life threatening disease in human being. NiV infection most RG-4 produced progressive serious or lethal human disease excessive infection which affects the central apprehensive and respiration structures. A PAPR or tight-fitting goggles and N-95 respirator should be kept in hand to avoid highrisk contaminated fine air droplets in respiratory infections in human beings. Scientific characteristics of NiV infection in Bangladesh, consisting of a severe breathing problem, seem distinct from scientific characteristics mentioned during advance outbreaks in other nations.
Most countries in the South-East Asia vicinity do not have adequate facilities to diagnose and control the virus. Therapeutic interventions are not usually available. There is need for further research to understand aetiology, ecology of the disease within reproductive cycles of bats \& transmission, clinical signs and symptoms of $\mathrm{NiV}$ infection. ${ }^{20}$

\section{Acknowledgements}

None.

\section{Conflict of interest}

Author declares there is no conflict of interest.

\section{References}

1. Institute of Epidemiology, Disease Control and Research. Nipah Infection. IEDCR; 2013.

2. World Health Organization. Global Early Warning System for Major Animal Diseases, including Zoonoses (GLEWS). Zoonoses \& Vet Pub Hlth. USA; 2007.

3. World Organisation for Animal Health. Manual of Diagnostic Tests and Vaccines for Terrestrial Animals. Paris; 2008.

4. Benjamin A, Satterfielda Brian E. Status of vaccine research and development of vaccines for Nipah virus. Vaccine. 2016;34(26):29712975.

5. Satterfield BA, Dawes BE, Milligan GN. Status of vaccine research and development of vaccines for Nipah virus. Vaccine. 2016;34(26):29712975.

6. Chatterjee P. Nipah virus outbreak in India. World Report. 2018;391:2200.

7. Chua KB, Goh KJ, Wong K. Fatal encephalitis due to Nipah virus among pig-farmers in Malaysia. Lancet. 1999;354(9186):1257-1259.

8. Giangaspero M. Nipah Virus, Tropical Medicine \& Surgery. 2013;1(4):1-4.

9. Kaku Y, Noguchi A, Marsh GA. Antigens capture ELISA system for Henipaviruses using polyclonal antibodies obtained by DNA immunization. Arch Virol. 2012;157(8):1605-1609.

10. Yen C, Hyde TB, Costa AJ. The development of global vaccine stockpiles. Lancet. 2015;15(3):340-347.

11. Clayton BA, Middleton D, Arkinstall R. The Nature of Exposure Drives Transmission of Nipah Viruses from Malaysia and Bangladesh in Ferrets. PLoS Negl Trop Dis. 2016:10(6):0004775.

12. Chakraborty A, Sazzad H, Hossain M. Evolving epidemiology of Nipah virus infection in Bangladesh: evidence from outbreaks during 2010-2011. Epidemiol Infect. 2016;144(2):371-380.

13. Clayton BA. Nipah virus: transmission of a zoonotic paramyxovirus. Curr Opin Virol. 2017;22:97-104.

14. World Health Organization (WHO). Regional Office for South-East Asia. Nipah virus outbreaks in the WHO South-East Asia Region. USA; 2010.

15. Clayton BA. Nipah virus: transmission of a zoonotic paramyxovirus. Curr Opin Viro. 2017;22:97-104.

16. Broder CC, Weir DL. Hendra virus and Nipah virus: animal vaccines. Vaccine. 2016;34(30):3525-3534.

17. World Organisation for Animal Health. Nipah and Hendra Virus Diseases, In: Manual of Diagnostic Tests and Vaccines for Terrestial Animals. 2015. p. 14. 
18. Kulkarni DD, Tosh C, Venkatesh G. Nipah virus infection: curren scenario. Indian J Virol. 2013;24(3):398-408.

19. Wong KT, Shieh WJ, Kumar S. Pathology and pathogenesis of an emerging paramyxoviral zoonosis. Am J Pathol. 2002;161(6):2153-2167.
20. Johara MY, Field H, Rashdi AM. Nipah virus infection in bats (order Chiroptera) in Peninsular Malaysia. Emerg Infect Dis. 2001;7(3):439-441. 